УДК : 327:341.123

\section{КЛАСИФІКАЦІЇ ЗАГРОЗ БЕЗПЕЦІ НА РЕГІОНАЛЬНОМУ ТА СУБРЕГІОНАЛЬНОМУ РІВНЯХ (НА ОСНОВІ РЕЗОЛЮЦІЙ ПЕРШОГО КОМІТЕТУ ГЕНЕРАЛЬНОЇ АСАМБЛЕЇ ООН)}

\section{Слюсаренко Ірина Юріївна}

кандидат історичних наук, доцент,

Київський університет ім. Бориса Грінченка, м. Київ, Україна

ORCID: 0000-0003-1451-627

i.sliusarenko@kubg.edu.ua
Надіслано:

15.06.2020

Рецензовано:

29.06.2020

Прийнято:

08.07.2020

Аналіз текстів резолюцій Першого комітету Генеральної Асамблеї ООН (ГА ООН) дозволяє виявити саме ті загрози, щодо яких існує консенсус більшості держав-членів ГА ООН. Мета дослідження - на основі аналізу текстів резолюцій Першого комітету ГА ООН (з роззброєння та міжнародної безпеки) за 2014-2019 рр. виявити загрози безпеці на регіональному та субрегіональному рівнях та здійснити їх класифікацію. За допомогою методу контент-аналізу російськомовних текстів резолюцій Першого комітету ГА ООН за 2014-2019 рр., де ключовими були такі одиниці аналізу: «загроза», «загроза безпеці», вдалося виокремити масив загроз безпеці на регіональному та субрегіональному рівнях. Метод кластерного аналізу дозволив систематизувати результати отримані в ході контент-аналізу за чітко визначеними параметрами: транскордонна загроза безпеці в Центральній Африці; ймовірне розповсюдження ядерної зброї на Близькому Сході; можливе використання терористами зброї масового знищення, міжнародних злочинів та незаконних відправлень зброї, а також незаконного виготовлення, споживання та торгівлі наркотиками в Середземномор'ї; загроза війни на регіональному рівні; загроза війни між державами одного регіону чи субрегіону; суперечки між державами. у текстах резолюцій Першого комітету ГА ООН виокремлено два основних підходи до класифікації загроз: за ступенем небезпеки та за актуальністю. Поєднання декількох класифікацій під час подальшого аналізу дасть уявлення про бачення міжнародним співтовариством сутності загроз у сфері міжнародної безпеки та роззброєння.

Ключові слова: загрози безпеки; регіональна безпека; класифікація; Близький Схід; Західна Африка; Середземномор'я; КНДР. 
Sliuarenko Iryna, Candidate of Historical Sciences, Associate Professor, Borys Grinchenko Kyiv University, Kyiv, Ukraine

Classification of the Security Threats at the Regional and Subregional Levels (Based on First Committee Resolutions of the United Nations General Assembly)

Analysis of the resolutions texts of the First Committee of the United Nations General Assembly (UN GA) allows us to identify exactly those threats on which there is a consensus of the majority of the UN GA member states. The purpose of the study is to identify security threats at the regional and subregional levels and to classify them based on the analysis of the resolutions texts of the UN GA First Committee (on disarmament and international security) for 2014-2019. The method of content analysis of Russian-language resolutions texts of the UN General Assembly's First Committee in 2014-2019, where the key units of analysis were "threat", "security threat", allowed to highlight an array of security threats at the regional and subregional levels. The method of cluster analysis allowed to systematize the results of the content analysis according to clearly defined parameters: cross-border security threat in Central Africa; the probable proliferation of nuclear weapons in the Middle East; terrorists may use weapons of mass destruction, international crimes and illicit shipments, as well as the illicit manufacture, consumption and trafficking of drugs in the Mediterranean; the threat of war at the regional level; the threat of war between the states of one region or subregion; disputes between states. In the texts of the resolutions of the First Committee of the UN General Assembly, two main approaches to the classification of threats are identified: according to the degree of danger and relevance. The combination of several classifications in the further analysis will give us an idea of the international community's vision of the essence of threats to international security and disarmament.

Key words: security threats; regional security; classification; Middle East; West Africa; Mediterranean; DPRK.

Слюсаренко Ирина Юрьевна, кандидат исторических наук, доцент, Киевский университет им. Бориса Гринченко, г. Киев, Украина

Классификации угроз безопасности на региональном и субрегиональном уровнях (на основе резолюций Первого комитета Генеральной Ассамблеи ООН)

Анализ текстов резолюций Первого комитета Генеральной Ассамблеи ООН (ГА ООН) позволяет выявить именно те угрозы, в отношении которых существует консенсус большинства государств-членов Генеральной Ассамблеи ООН. Цель исследования - на основе анализа текстов резолюций Первого комитета ГА ООН (по разоружению и международной безопасности) в 2014-2019 гг. выявить угрозы безопасности на региональном и 
субрегиональном уровнях и классифицировать их. С помощью метода контентанализа русскоязычных текстов резолюций Первого комитета ГА ООН в 2014-2019 гг., где ключевыми были такие единицы анализа как «угроза», «угроза безопасности», удалось выделить массив угроз безопасности на региональном и субрегиональном уровнях. Метод кластерного анализа позволил систематизировать результаты контент-анализа по четко определенным параметрам: трансграничная угроза безопасности в Центральной Африке; вероятно распространения ядерного оружия на Ближнем Востоке; возможно использование террористами оружия массового поражения, международных преступлений и незаконных отправлений оружия, а также незаконного изготовления, потребления и торговли наркотиками в Средиземноморье; угроза войны на региональном уровне; угроза войны между государствами одного региона или субрегиона; споры между государствами. В текстах резолюций Первого комитета ГА ООН выделены два основных подхода к классификации угроз: по степени опасности и по актуальности. Сочетание нескольких классификаций, при дальнейшем анализе, даст представление о видении международным сообществом сущности угроз в сфере международной безопасности и разоружения.

Ключевые слова: угрозы безопасности; региональная безопасность; классификация; Ближний Восток; Западная Африка; Средиземноморье; КНДР.

\section{Вступ}

Важливою складовою міжнародною безпеки є ті загрози, які виникають або можуть виникнути в найближчому майбутньому на регіональному або субрегіональному рівнях. Усвідомлення міжнародним співтовариством сутності цих загроз дозволить прийняти рішення щодо їх ліквідації або нейтралізації. ООН залишається найвпливовішою міжнародною організацією, яка має необхідні механізми для узгодження спільного бачення сутності загроз з боку 193 держав-учасниць та надавання рекомендацій/вимог щодо їх усунення. Аналіз текстів резолюцій Першого комітету ГА ООН завдяки специфіці їх ухвалення, дозволяє виділити саме ті, загрози, щодо актуальності яких існує узгоджена позиція більшості держав-членів. Класифікація загроз за ступенем небезпеки та актуальністю дозволила б оптимізувати зусилля міжнародної спільноти, спрямовані на їх зменшення або усунення.

\section{Аналіз останніх досліджень та публікацій}

Проблема класифікації загроз міжнародній безпеці розглядалася у наукових дослідженнях низки авторів. Так, російські вчені А. Абашидзе та Г. Гусейнова (Abashydze, Ghusejnova, 2017) у своїй науковій роботі під час класифікації загроз послуговуються доповіддю Групи високого рівня з питань загроз, викликів і змін «Безпечніший світ: наша спільна відповідальність» від 
2 грудня 2004 р., де надається визначення загроз та вказуються блоки загроз: «Будь-яка подія або процес, які ведуть до масової загибелі людей або зменшення шансів на виживання і послаблюють держави як базові елементи міжнародної системи, являють собою загрозу міжнародній безпеці.

Якщо виходити з цього визначення, то існує шість блоків загроз, якими світ повинен займатися зараз і в майбутні десятиліття: економічні та соціальні загрози, включаючи злидні, інфекційні хвороби та екологічну деградацію; міждержавні конфлікти; внутрішні конфлікти, включаючи громадянську війну, геноцид й інші масові звірства; ядерна, радіологічна, хімічна та біологічна зброя; тероризм; транснаціональна організована злочинність» (UN, 2004).

Ще один підхід до класифікації загроз подає у вступній частині колективної монографії «Нові загрози та нові актори міжнародної безпеки» Е. Крахман, де вказує на нові загрози безпеки, до яких відносить тероризм і транснаціональну злочинність, розповсюдження зброї масового знищення, громадянські війни та етнічні конфлікти, ВІЛ/СНІД, поширення легкої та стрілецької зброї (Krahmann, 2005, p. 7).

С. Патрік аналізує такі глобальні загрози для США та міжнародної безпеки: міжнародний тероризм, поширення зброї масового знищення, транснаціональну злочинність, енергетичну незахищеність, основні інфекційні захворювання (Patrick, 2011, p. 9).

У Довідниках 3 практики Ради Безпеки ОOH (UN, 2015d) загрози поділяються на два типи: нові загрози та загрози, які зберігаються.

Саме остання класифікація, за часом виникнення: нові та загрози, що зберігаються, разом із класифікацією за сутністю: загрози міжнародному миру та безпеці, загрози міжнародному миру та безпеці, які створюють терористичні акти, були використані під час дослідження загроз міжнародній безпеці в нових геополітичних умовах (Sliusarenko, 2018, p. 34.)

\section{Виділення невирішених раніше частин загальної проблеми}

Серед вищезазначених досліджень відсутні класифікації загроз міжнародній безпеці та роззброєнню на регіональному та субрегіональному рівні міжнародних відносин у нових геополітичних умовах, які б спиралися на широку джерельну базу, а саме: резолюції Першого комітету ГА ООН, тексти яких містять узгоджену думку більшості держав-членів все ще найпотужнішої міжнародної універсальної організації.

\section{Формулювання цілей статті}

Метою цього дослідження є здійснення класифікації загроз безпеці на регіональному та субрегіональному рівнях на основі аналізу текстів резолюцій Першого комітету комітет із питань роззброєння та міжнародної безпеки ГА ООН за 2014-2019 pр. Досягнення мети дослідження можливе за умови послідовного виконання наступних завдань: аналізу текстів резолюцій 
Першого комітету (з питань роззброєння та міжнародної безпеки) ГА ООН за 2014-2019 рр.; визначення за допомогою контент-аналізу загроз безпеці на регіональному та субрегіональному рівнях; здійснення класифікації визначених загроз за наростанням та актуальністю.

\section{Виклад основного матеріалу дослідження}

у текстах резолюцій ГА ООН консолідується думка міжнародної спільноти щодо актуальних загроз у питанні роззброєння та міжнародної безпеки, класифікація яких дозволить оптимізувати процес ухвалення рішень на рівні керівних органів ООН.

Аналіз текстів російськомовних резолюцій вищевказаного комітету під час LXIX-LXXIV сесій ГА ООН упродовж 2014-2019 pр. здійснювався за допомогою методу контент-аналізу, де ключовими стали такі одиниці: «угроза», «угроза безопасности». Під час аналізу враховувалася особливість перекладу «угроза» 3 російської мови на українську мову, оскільки за смисловим навантаженням даний термін може вживатися і як «загроза», і як «погроза». Були відібрані лише ті результати, які вживаються саме як «загроза» безпеці та стосуються конкретних регіонів або субрегіонів - Центральної Африки, Близького Сходу, району Середземномор'я.

Кластерний аналіз дозволив систематизувати отримані результати загроз за наступними параметрами: транскордонні загрози безпеці в Центральній Африці; ймовірне розповсюдження ядерної зброї на Близькому Сході; можливе застосування терористами зброї масового знищення, міжнародна злочинність і незаконні поставки зброї, а також незаконне виробництво, споживання та обіг наркотиків у районі Середземномор'я; загроза війни на регіональному рівні; загроза виникнення війни між державами одного регіону або субрегіону; суперечки між державами. Зазначимо, що також в окремі роки у текстах резолюцій ГА ООН чітко вказуються як загрози: ядерна та ракетна програми КНДР у 2016-2018 рр. та арабо-ізраїльський конфлікт - 2018 р.

Проте рівень вищезазначених загроз у текстах резолюцій Першого комітету ГА ООН різниться, тому всі згадані загрози потрібно ранжувати також і за ступенем небезпеки. За наростанням загрози класифікація виглядає наступним чином:

- загроза;

- загроза для безпеки та стабільності регіону;

- серйозна загроза миру, безпеці і стабільності в районі;

- транскордонні загрози безпеці;

- загроза миру і безпеці;

- загроза підтриманню міжнародного миру і безпеки;

- загроза для міжнародного миру та безпеки; 
- серйозна загроза міжнародному миру та безпеці;

- безпрецедентна, серйозна і безпосередня загроза для миру і безпеки в регіоні і в усьому світі.

Поєднання декількох класифікацій дасть нам картину бачення міжнародним співтовариством сутності загроз безпеці, зокрема на регіональному та субрегіональному рівнях, яке відзеркалено в текстах ухвалених резолюцій ГА ООН, а отже, є позицією більшості держав-членів ООН з цієї проблеми.

У текстах резолюцій, присвячених заходам зміцнення довіри на регіональному рівні, пов'язаних з діяльністю Постійного консультативного комітету Організації Об'єднаних Націй з питань безпеки в Центральній Африці, виокремлюється загроза, яку становить для регіону басейну озера Чад терористична група «Боко харам» (UN, 2014b; UN, 2015b; UN, 2016c; UN, 2017c; UN, 2018c; UN, 2019b).

Ще одним різновидом загроз є «загроза війни», яка наявна в текстах резолюцій ГА ООН, присвячених регіональному роззброєнню (UN, 2014е; UN, 2015c; UN, 2016d; UN, 2017e; UN, 2018g; UN, 2019d).

Розповсюдження ядерної зброї на Близькому Сході згадується двічі. Уперше як загроза для безпеки та стабільності регіону: «... Ізраїль залишається єдиною державою на Близькому Сході, яка ще не стала учасником Договору (ДНЯ3), будучи стурбована загрозою, яку розповсюдження ядерної зброї створює для безпеки та стабільності регіону Близького Сходу, підкреслюючи важливість прийняття заходів зміцнення довіри, зокрема створення зони, вільної від ядерної зброї, на Близькому Сході, в цілях зміцнення миру і безпеки в регіоні та зміцнення режиму нерозповсюдження на глобальному рівні» (UN, 2014d).

У текстах резолюцій, присвячених зміцненню безпеки та співробітництва в районі Середземномор'я (UN, 2014f; UN, 2015e; UN, 2016e; UN, 2017f; UN, 2018h; UN, 2019e), ГА ООН «рекомендує країнам Середземномор'я і далі зміцнювати своє співробітництво в боротьбі з тероризмом у всіх його формах і проявах, включаючи можливе застосування терористами зброї масового знищення, беручи до уваги відповідні резолюції Організації Об’єднаних Націй, і в боротьбі з міжнародною злочинністю i незаконними поставками зброї, а також незаконними виробництвом, споживанням та обігом наркотиків, які створюють серйозну загрозу миру,безпеці та стабільності в цьому районі» (UN, 2013).

Серозними $\epsilon$ проблеми із забезпеченням безпеки для Центральної Африки, де дії «Боко харам» і «Армії опору Бога», акти піратства та озброєних пограбувань на морі в Гвінейській затоці, а також побічні наслідки ситуації в Лівії і кризи в Малі становлять транскордонні загрози безпеці (UN, 2014c; UN, 2015b; UN, 2016c; UN, 2017d; UN, 2018c; UN, 2019c). Потрібно зазначити, 
що в тексті резолюції ГА ООН 73/78 «Меры укрепления доверия на региональном уровне: деятельность Постоянного консультативного комитета Организации Объединенных Наций по вопросам безопасности в Центральной Африке» від 5 грудня 2018 р. до переліку загроз також було додано проблеми сезонного перегону худоби (UN, 2018c)

Як зазначається в низці резолюцій ГА ООН, присвячених контролю над звичайними озброєннями на регіональному та субрегіональному рівнях, більшість загроз миру $і$ безпеці в епоху після закінчення холодної війни виникає головним чином у відносинах між державами, розташованими в одному і тому ж регіоні або субрегіоні (UN, 2014a; UN, 2015a; UN, 2016b; UN, 2017b; UN, 2018b; UN, 2019a).

Продовження суперечок між державами, особливо за відсутності ефективного механізму, що дозволяє вирішувати їх за допомогою мирних засобів, може посилити гонку озброєнь і створити загрозу підтриманню міжнародного миру та безпеці (UN, 2014c; UN, 2017d; UN, 2018е; UN, 2019c).

Ізраїльсько-палестинський конфлікт згадується лише 2018 року, саме як загроза для міжнародного миру та безпеки: «...Організації Об'єднаних Націй в цілому настійно необхідно активізувати зусилля з тим, щоб ізраїльськопалестинський конфлікт, який як і раніше являє загрозу для міжнародного миру та безпеки, як можна швидше було врегульовано, що дозволить встановити справедливий і міцний мир в регіоні» (UN, 2018f).

2016 року серед усіх згаданих у резолюціях ГА ООН загроз актуалізується (UN, 2016а), а вже 2017 та 2018 року найбільшу небезпеку становить ядерна програма Корейської Народно-Демократичної Республіки (UN, 2017a; UN, 2018a), оскільки «неодноразові і часті незаконні ядерні випробування і запуски 3 використанням технології балістичних ракет, проведені Корейською НародноДемократичною Республікою, зокрема проведене нею 3 вересня 2017 року ядерне випробування, яке, за їі словами, було пов'язано з водневою бомбою для міжконтинентальної балістичної ракети, і два пуски балістичних ракет, які пролетіли над Японією 29 серпня і 15 вересня 2017 року, створюють безпрецедентну, серйозну і безпосередню загрозу для миру $і$ безпеки в регіоні $і$ в усьому світі» (UN, 2017a).

Ще однією класифікацією є поділ вищезазначених загроз за актуальністю на наявні та гіпотетичні/ймовірні.

Так, до наявних загроз відносяться: ядерна програма КНДР; дії «Боко харам» і «Армії опору Бога», акти піратства та озброєних пограбувань на морі в Гвінейській затоці, а також побічні наслідки ситуації в Лівії і кризи в Малі; міжнародна злочинність і незаконні поставки зброї, а також незаконне виробництво, споживання та обіг наркотиків і районі Середземномор'я та ізраїльсько-палестинський конфлікт. 


\section{Слюсаренко Ірина Юріївна \\ Класифікація загроз безпеці на регіональному та субрегіональному рівнях (на основі резолюцій Першого комітету Генеральної Асамблеї 00Н)}

До гіпотетичних/ймовірних загроз належать такі:

- можливість розповсюдження ядерної зброї на Близькому Сході;

- застосування терористами зброї масового знищення в районі Середземномор'я.

Відразу до обох типів відносяться продовження суперечок між державами та відносини між державами, розташованими в одному і тому ж регіоні або субрегіоні, оскільки залежно від регіону ці загрози вже наявні, або лише можуть виникнути.

\section{Висновки}

У текстах Першого комітету ГА ООН можна виокремити два основних підходи до класифікації загроз: за ступенем небезпеки та за актуальністю.

За ступенем безпеки за наростанням загрози класифікація виглядає наступним чином: загроза; загроза для безпеки та стабільності регіону; серйозна загроза миру, безпеці і стабільності в районі; транскордонні загрози безпеці; загроза миру і безпеці; загроза підтриманню міжнародного миру і безпеки; загроза для міжнародного миру та безпеки; серйозна загроза міжнародному миру та безпеці; безпрецедентна, серйозна і безпосередня загроза для миру і безпеки в регіоні і в усьому світі.

За актуальністю загрози виділяємо два типи загроз: наявні та гіпотетичні/ймовірні. Зазначимо також, що загрози безпеці пов'язані з такими регіонами та субрегіонами як Центральна Африка, район Середземномор'я та Близький Схід. Саме в останньому регіоні загроза поширення ядерної зброї носить гіпотетичний характер, як і застосування зброї масового знищення терористами в районі Середземномор'я. Відзначимо, що найсерйозніша загроза, не лише регіонального рівня, але й глобального, $є$ актуалізованою та пов'язана із ядерною та ракетною програмою КНДР.

\section{References:}

1. Abashydze A., Ghusejnova H. (2017) 'Sovremennye uhrozy e vyzovy mezhdunarodnoi bezopasnosty cherez pryzmu Ustava 00N. Chast 1' [Modern threats and challenges to international security through the prism of the UN Charter. Part 1]. Nauchno-analitycheskij zhurnal. Obozrevatel-Observer. Vol. 8 (331), [online]. Available at: http://materik.ru/upload/iblock/301/301d0bed68283842c282456157fef348.pdf.

2. Krahmann, E. (Ed). (2005). New threats and new actors in international security. Springer.

3. Patrick, S. (2011). Weak links: fragile states, global threats, and international security. Oxford University Press.

4. Sliusrenko I., (2018). 'Zagrozy mazhnarodhiy bezpeci v novykh geopolitychnych ymovach' [Threats of international security in new geopolitical conditions]. Hileia: naukovyj visnyk [Gilea: scientific bulletin], issue 138 (3), pp. 30-34. 
5. United Nations (UN). (2004). Transmittal letter dated 1 December 2004 from the Chair of the High-level Panel on Threats, Challenges and Change addressed to the Secretary-General A/59/565l. United Nations, [online]. Available at: https://www.unog.ch/80256EDD006B8954/(httpAssets)/C9B1B6D819968E83C1256 F5E00597208/\$file/Report+of+the+High-

level+Panel+on+Threats+Challenges+and+Change.pdf.

6. United Nations (UN). (2013). Ukreplenie bezopasnosti i sotrudnichestva $\mathrm{v}$ rayone Sredizemnomorya: Rezoljucija General'noj Assambleej A/RES/68/67 ot 5 dekabrja 2013 goda [Strengthening of security and cooperation in the Mediterranean region: UN General Assembly Resolution A/RES/68/67 dated December 5, 2013]. United Nations, [online]. Available at: https://undocs.org/ru/A/RES/68/67.

7. United Nations (UN). (2014a). Kontrol nad obyichnyimi vooruzheniyami na regionalnom i subregionalnom urovnyah: Rezoljucija General'noj Assambleej A/RES/69/47 ot 2 dekabrja 2014 goda [Conventional arms control at the regional and subregional levels: UN General Assembly Resolution A/RES/69/47 dated December 2, 2014]. United Nations, [online]. Available at: https://undocs.org/ru/A/RES/69/47.

8. United Nations (UN). (2014b). Meryi ukrepleniya doveriya na regionalnom urovne: deyatelnost Postoyannogo konsultativnogo komiteta Organizatsii Ob'edinennyih Natsiy po voprosam bezopasnosti v Tsentralnoy Afrike: Rezoljucija General'noj Assambleej A/RES/69/73 ot 2 dekabrja 2014 goda [Regional confidencebuilding measures: activities of the United Nations Standing Advisory Committee on Security Questions in Central Africa: UN General Assembly Resolution A/RES/69/73 dated December 2, 2014]. United Nations, [online]. Available at: https://undocs.org/ru/A/RES/69/73.

9. United Nations (UN). (2014c). Meryi ukrepleniya doveriya $v$ regionalnom $i$ subregionalnom kontekste: Rezoljucija General'noj Assambleej A/RES/69/46 ot 2 dekabrja 2014 goda [Confidence-building measures in the regional and subregional context: UN General Assembly Resolution A/RES/69/46 dated December 2, 2014]. United Nations, [online]. Available at: https://undocs.org/ru/A/RES/69/46.

10. United Nations (UN). (2014d). Opasnost rasprostraneniya yadernogo oruzhiya na Blizhnem Vostoke: Rezoljucija General'noj Assambleej A/RES/69/78 ot 2 dekabrja 2014 goda [The risk of nuclear proliferation in the Middle East: UN General Assembly Resolution A/RES/69/78 dated December 2, 2014]. United Nations, [online]. Available at: https://undocs.org/ru/A/RES/69/78.

11. United Nations (UN). (2014e). Regionalnoe razoruzhenie: Rezoljucija General'noj Assambleej A/RES/69/45 ot 2 dekabrja 2014 goda [Regional disarmament: UN General Assembly Resolution /A/RES/69/45 dated December 2, 2014]. United Nations, [online]. Available at: https://undocs.org/ru/A/RES/69/45.

12. United Nations (UN). (2014f). Ukreplenie bezopasnosti i sotrudnichestva $v$ rayone Sredizemnomorya: Rezoljucija General'noj Assambleej A/RES/69/80 ot 2 
dekabrja 2014 goda [Strengthening of security and cooperation in the Mediterranean region] : UN General Assembly Resolution A/RES/69/80 dated December 2, 2014]. United Nations, [online]. Available at: https://undocs.org/ru/A/RES/69/80.

13. United Nations (UN). (2015a). Kontrol nad obyichnyimi vooruzheniyami na regionalnom i subregionalnom urovnyah: Rezoljucija General'noj Assambleej A/RES/70/44 ot 7 dekabrja 2015 goda [Conventional arms control at the regional and subregional levels: UN General Assembly Resolution A/RES/70/44 dated December 7, 2015]. United Nations, [online]. Available at: https://undocs.org/ru/A/RES/70/44.

14. United Nations (UN). (2015b). Meryi ukrepleniya doveriya na regionalnom urovne: deyatelnost Postoyannogo konsultativnogo komiteta Organizatsii Ob'edinennyih Natsiy po voprosam bezopasnosti v Tsentralnoy Afrike: Rezoljucija General'noj Assambleej A/RES/70/64 ot 7 dekabrja 2015 goda [Regional confidencebuilding measures: activities of the United Nations Standing Advisory Committee on Security Questions in Central Africa: UN General Assembly Resolution A/RES/70/64 dated December 7, 2015]. United Nations, [online]. Available at: https://www.undocs.org/ru/A/RES/70/64.

15. United Nations (UN). (2015c). Regionalnoe razoruzhenie: Rezoljucija General'noj Assambleej A/RES/70/43 ot 7 dekabrja 2015 goda [Regional disarmament: UN General Assembly Resolution/A/RES/70/43 dated December 7, 2015]. United Nations, [online]. Available at: https://undocs.org/ru/A/RES/70/43.

16. United Nations (UN). (2015d). Repertoire of the Practice of the Security Council 19th Supplement 2014-2015. United Nations, [online]. Available at: <http://www.un.org/en/sc/repertoire/2014-2015/Part_VII/20142015_Part_VII.pdf\#page=7>.

17. United Nations (UN). (2015e). Ukreplenie bezopasnosti i sotrudnichestva $v$ rayone Sredizemnomorya: Rezoljucija General'noj Assambleej A/RES/70/72 ot 7 dekabrja 2015 goda [Strengthening of security and cooperation in the Mediterranean region: UN General Assembly Resolution A/RES/70/72 dated December 7, 2015]. United Nations, [online]. Available at: https://www.undocs.org/ru/A/RES/70/72.

18. United Nations (UN). (2016a). Bolee reshitelnyie sovmestnyie deystviya $v$ tselyah polnoy likvidatsii yadernogo oruzhiya: Rezoljucija General'noj Assambleej A/RES/71/49 ot 5 dekabrja 2016 goda [United action with renewed determination towards the total elimination of nuclear weapons: UN General Assembly Resolution A/RES/71/49 dated December 5, 2016]. United Nations, [online]. Available at: https://undocs.org/ru/A/RES/71/49.

19. United Nations (UN). (2016b). Kontrol nad obyichnyimi vooruzheniyami na regionalnom i subregionalnom urovnyah: Rezoljucija General'noj Assambleej A/RES/71/41 ot 5 dekabrja 2016 goda [Conventional arms control at the regional and subregional levels: UN General Assembly Resolution A/RES/71/41 dated December 5, 2016]. United Nations, [online]. Available at: https://undocs.org/ru/A/RES/71/41. 
20. United Nations (UN). (2016c). Meryi ukrepleniya doveriya na regionalnom urovne: deyatelnost Postoyannogo konsultativnogo komiteta Organizatsii Ob'edinennyih Natsiy po voprosam bezopasnosti v Tsentralnoy Afrike: Rezoljucija General'noj Assambleej A/RES/71/79 ot 5 dekabrja 2016 goda [Regional confidencebuilding measures: activities of the United Nations Standing Advisory Committee on Security Questions in Central Africa: UN General Assembly Resolution A/RES/71/79 dated December 5, 2016]. United Nations, [online]. Available at: https://undocs.org/ru/A/RES/71/79.

21. United Nations (UN). (2016d). Regionalnoe razoruzhenie: Rezoljucija General'noj Assambleej A/RES/71/40 ot 5 dekabrja 2016 goda [Regional disarmament: UN General Assembly Resolution /A/RES/71/40 dated December 5, 2016]. United Nations, [online]. Available at: https://undocs.org/ru/A/RES/71/40.

22. United Nations (UN). (2016e). Ukreplenie bezopasnosti i sotrudnichestva $\mathrm{V}$ rayone Sredizemnomorya: Rezoljucija General'noj Assambleej A/RES/71/85 ot 5 dekabrja 2016 goda [Strengthening of security and cooperation in the Mediterranean region: UN General Assembly Resolution A/RES/71/85 dated December 5, 2016]. United Nations, [online]. Available at: https://undocs.org/ru/A/RES/71/85.

23. United Nations (UN). (2017a). Bolee reshitelnyie sovmestnyie deystviya $\mathrm{v}$ tselyah polnoy likvidatsii yadernogo oruzhiya: Rezoljucija General'noj Assambleej A/RES/72/50 ot 4 dekabrja 2017 goda [United action with renewed determination towards the total elimination of nuclear weapons: UN General Assembly Resolution A/RES/72/50 dated December 4, 2017]. United Nations, [online]. Available at: https://undocs.org/ru/A/RES/72/50.

24. United Nations (UN). (2017b). Kontrol nad obyichnyimi vooruzheniyami na regionalnom i subregionalnom urovnyah: Rezoljucija General'noj Assambleej A/RES/72/35 ot 4 dekabrja 2017 goda [Conventional arms control at the regional and subregional levels: UN General Assembly Resolution A/RES/72/35 dated December 4, 2017]. United Nations, [online]. Available at: https://www.undocs.org/ru/A/RES/72/35.

25. United Nations (UN). (2017c). Meryi ukrepleniya doveriya na regionalnom urovne: deyatelnost Postoyannogo konsultativnogo komiteta Organizatsii Ob'edinennyih Natsiy po voprosam bezopasnosti v Tsentralnoy Afrike: Rezoljucija General'noj Assambleej A/RES/72/63 ot 4 dekabrja 2017 goda [Regional confidencebuilding measures: activities of the United Nations Standing Advisory Committee on Security Questions in Central Africa: UN General Assembly Resolution A/RES/72/63 dated December 4, 2017]. United Nations, [online]. Available at: https://undocs.org/ru/A/RES/72/63.

26. United Nations (UN). (2017d). Meryi ukrepleniya doveriya v regionalnom i subregionalnom kontekste: Rezoljucija General'noj Assambleej A/RES/72/33 ot 4 dekabrja 2017 goda [Confidence-building measures in the regional and subregional 


\section{Слюсаренко Ірина Юріївна \\ Класифікація загроз безпеці на регіональному та субрегіональному рівнях (на основі резолюцій Першого комітету Генеральної Асамблеї 00Н)}

context: UN General Assembly Resolution A/RES/72/33 dated December 4, 2017]. United Nations, [online]. Available at: https://www.undocs.org/ru/A/RES/72/33.

27. United Nations (UN). (2017e). Regionalnoe razoruzhenie: Rezoljucija General'noj Assambleej A/RES/72/34 ot 4 dekabrja 2017 goda [Regional disarmament: UN General Assembly Resolution /A/RES/72/34 dated December 4, 2017]. United Nations, [online]. Available at: https://undocs.org/ru/A/RES/72/34.

28. United Nations (UN). (2017f). Ukreplenie bezopasnosti i sotrudnichestva $v$ rayone Sredizemnomorya: Rezoljucija General'noj Assambleej A/RES/72/69 ot 4 dekabrja 2017 goda [Strengthening of security and cooperation in the Mediterranean region: UN General Assembly Resolution A/RES/72/69 dated December 4, 2017]. United Nations, [online]. Available at: https://www.undocs.org/ru/A/RES/72/69.

29. United Nations (UN). (2018a). Bolee reshitelnyie sovmestnyie deystviya $\mathrm{v}$ tselyah polnoy likvidatsii yadernogo oruzhiya: Rezoljucija General'noj Assambleej A/RES/73/62 ot 5 dekabrja 2018 goda [United action with renewed determination towards the total elimination of nuclear weapons: UN General Assembly Resolution A/RES/73/62 dated December 5, 2018]. United Nations, [online]. Available at: https://undocs.org/ru/A/RES/73/62.

30. United Nations (UN). (2018b). Kontrol nad obyichnyimi vooruzheniyami na regionalnom i subregionalnom urovnyah: Rezoljucija General'noj Assambleej A/RES/73/34 ot 5 dekabrja 2018 goda [Conventional arms control at the regional and subregional levels: UN General Assembly Resolution A/RES/73/34 dated December 5, 2018], United Nations, [online]. Available at: https://undocs.org/ru/A/RES/73/34 [Accessed 9 March 2020].

31. United Nations (UN). (2018c). Meryi ukrepleniya doveriya na regionalnom urovne: deyatelnost Postoyannogo konsultativnogo komiteta Organizatsii Ob'edinennyih Natsiy po voprosam bezopasnosti v Tsentralnoy Afrike: Rezoljucija General'noj Assambleej A/RES/73/78 ot 5 dekabrja 2018 goda [Regional confidencebuilding measures: activities of the United Nations Standing Advisory Committee on Security Questions in Central Africa: UN General Assembly Resolution A/RES/73/78 dated December 5, 2018]. United Nations, [online]. Available at: https://undocs.org/ru/A/RES/73/78.

32. United Nations (UN). (2018d). Informatsionnaya programma Organizatsii Ob'edinennykh Natsiy po razoruzheniyuu: Rezoljucija General'noj Assambleej A/RES/73/79 ot 5 dekabrja 2018 goda [United Nations Disarmament Information Programme: UN General Assembly Resolution A/RES/73/79 dated December 5, 2018]. United Nations, [online]. Available at: https://undocs.org/ru/A/RES/73/79.

33. United Nations (UN). (2018e). Meryi ukrepleniya doveriya $v$ regionalnom $i$ subregionalnom kontekste: Rezoljucija General'noj Assambleej A/RES/73/35 ot 5 dekabrja 2018 goda [Confidence-building measures in the regional and subregional 
context: UN General Assembly Resolution A/RES/73/35 dated December 5, 2018]. United Nations, [online]. Available at: https://undocs.org/ru/A/RES/73/35.

34. United Nations (UN). (2018f). Mirnoe uregulirovanie voprosa o Palestine: Rezoljucija General'noj Assambleej A/RES/73/19 ot 5 dekabrja 2018 goda [Peaceful settlement of the question of Palestine: UN General Assembly Resolution A/RES/73/19 dated December 5, 2018]. United Nations, [online]. Available at: https://undocs.org/ru/A/RES/73/19.

35. United Nations (UN). (2018g). Regionalnoe razoruzhenie: Rezoljucija General'noj Assambleej A/RES/73/33 ot 5 dekabrja 2018 goda [Regional disarmament: UN General Assembly Resolution /A/RES/73/33 dated December 5, 2018]. United Nations, [online]. Available at: https://undocs.org/ru/A/RES/73/33.

36. United Nations (UN). (2018h). Ukreplenie bezopasnosti i sotrudnichestva $\mathrm{v}$ rayone Sredizemnomorya: Rezoljucija General'noj Assambleej A/RES/73/85 ot 5 dekabrja 2018 goda [Strengthening of security and cooperation in the Mediterranean region: UN General Assembly Resolution A/RES/73/85 dated December 5, 2018]. United Nations, [online]. Available at: https://undocs.org/ru/A/RES/73/85.

37. United Nations (UN). (2019a). Kontrol nad obyichnyimi vooruzheniyami na regionalnom i subregionalnom urovnyah: Rezoljucija General'noj Assambleej A/RES/74/38 ot 12 dekabrja 2019 goda [Conventional arms control at the regional and subregional levels: UN General Assembly Resolution A/RES/74/38. United Nations, [online]. Available at: https://undocs.org/ru/A/RES/74/38.

38. United Nations (UN). (2019b). Meryi ukrepleniya doveriya na regionalnom urovne: deyatelnost Postoyannogo konsultativnogo komiteta Organizatsii Ob'edinennyih Natsiy po voprosam bezopasnosti v Tsentralnoy Afrike: Rezoljucija General'noj Assambleej A/RES/74/73 ot 12 dekabrja 2019 goda [Regional confidencebuilding measures: activities of the United Nations Standing Advisory Committee on Security Questions in Central Africa: UN General Assembly Resolution A/RES/74/73 dated December 12, 2019]. United Nations, [online]. Available at: https://undocs.org/ru/A/RES/74/73.

39. United Nations (UN). (2019c). Meryi ukrepleniya doveriya $v$ regionalnom i subregionalnom kontekste: Rezoljucija General'noj Assambleej A/RES/74/39 ot 12 dekabrja 2019 goda [Confidence-building measures in the regional and subregional context: UN General Assembly Resolution A/RES/74/39 dated December 12, 2019]. United Nations, [online]. Available at: https://undocs.org/ru/A/RES/74/39.

40. United Nations (UN). (2019d). Regionalnoe razoruzhenie: Rezoljucija General'noj Assambleej A/RES/74/37 ot 12 dekabrja 2019 goda [Regional disarmament: UN General Assembly Resolution /A/RES/74/37 dated December 12, 2019]. United Nations, [online]. [online]. Available at: https://undocs.org/ru/A/RES/74/37. 
41. United Nations (UN). (2019e). Ukreplenie bezopasnosti i sotrudnichestva $\mathrm{v}$ rayone Sredizemnomorya: Rezoljucija General'noj Assambleej A/RES/74/77 ot 12 dekabrja 2019 goda [Strengthening of security and cooperation in the Mediterranean region: UN General Assembly Resolution /A/RES/74/77 dated December 12, 2019]. United Nations, [online]. Available at: https://undocs.org/ru/A/RES/74/77.

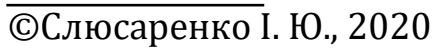

